\title{
Comparative Analysis of Beet Juice and Red Guava Juice against Erythrocyte and Hematocrit Levels in Post-partum Women
}

\author{
Cut Nurhasanah*, Andri Idiana, Putri Santi, Yushida Yushida \\ Department of Midwifery, Polytechnic of Health, Ministry of Health, Aceh, Indonesia
}

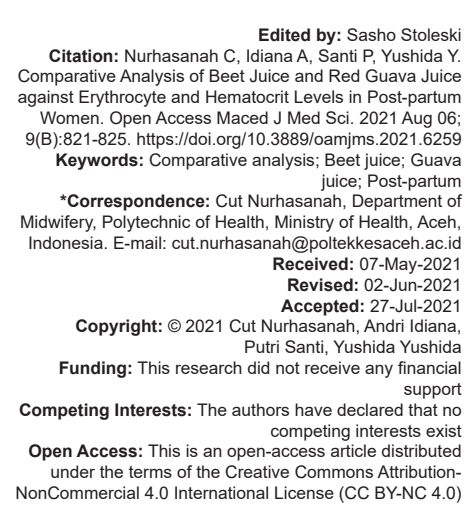

\section{Introduction}

According to the World Health Organization, anemia affects about 1.5 billion people worldwide. The prevalence is very high in Africa, Asia, India, Latin America, Eastern Europe, and China; however, this rate is also high in developed countries [1]. Globally, anemia in pregnancy is a severe hematologic disorder affecting 32.4 million pregnant women [2].

The association between high hemoglobin (Hb) and hematocrit (HTC) levels and complications such as preterm labor, low birth weight, intrauterine growth restriction, and intrauterine fetal death has also been demonstrated in several studies [3].

According to Stoev et al. carried out in Bulgarian pregnant women, an increase in $\mathrm{HTC}, \mathrm{Hb}$, and red blood cell (RBC) mass in early pregnancy can be considered a risk factor for preeclampsia, intrauterine growth restriction, and fetal death in the later stages of pregnancy [4]. The puerperium is divided into three phases, namely, the acute phase - the first $24 \mathrm{~h}$ after the placenta is born, early - up to 7 days, and late - up to 6 weeks to 6 months; each phase has its unique clinical considerations and challenges [5], [6].

Iron (Fe) deficiency has been associated with maternal and perinatal morbidity during the postpartum period, including postpartum depression, impaired motherchild interaction, maternal stress, and impaired cognitive function [7], [8], [9]. Fe requirements increase exponentially during pregnancy to meet the increased demand for the fetoplacental unit, increase maternal erythrocyte mass and compensate for $\mathrm{Fe}$ loss during labor [10], [11]. A study found that maternal age, education, family income, religion, number of family members at home, and children's number were determinants that contributed to anemia [12]. Postpartum maternal anemia may be associated with shortness of breath, lethargy, infection, lactation failure, and depression [13], [14]. Postpartum mothers who experience anemia can cause bleeding, nutrition, and insufficient breast milk, leading to the failure of exclusive breastfeeding and malnutrition in infants. This condition 
strengthens the formation of a cycle of malnutrition in children under five, and the next cycle, if it is not successful, is decided by efforts to prevent and treat anemia in postpartum mothers [15]. To prevent and treat anemia in postpartum mothers, one government program is to provide $\mathrm{Fe}$ tablets from pregnancy to postpartum for 1 month. Besides, mothers are encouraged to consume foods in the form of vegetables or fruit that contain high $\mathrm{Fe}$ and Vitamins that help $\mathrm{Fe}$ absorption faster [15].

Nonpharmacological treatment can use vegetables and fruits that are simple and easy to obtain. One of the fruits that can increase $\mathrm{Hb}$ levels in pregnant women is guava and beets. Today, beets are grown in many countries worldwide, are regularly consumed as part of food, and are commonly used in factories as food coloring [16], [17]. Beets have many advantages for health and medicine. The betanin content in beets is helpful as an anti-cancer because these substances can destroy tumors and cancer cells. Beets (Beta vulgaris) contain $109 \mathrm{mg}$ of folic acid and $10.0 \mathrm{mg}$ of Vitamin C. The incidence of anemia reached $18.4 \%$, while in Aceh Besar District, anemia's incidence reached 15.3\%. Data at the Darul Imarah Health Center, the number of postpartum mothers with mild anemia, is 579 people, moderate anemia is 99 people, and severe anemia is eight people. The research objective was to compare beet juice with red guava juice on erythrocyte and HTC levels in postpartum mothers in the Darul Imarah Health Center, Aceh Besar District.

\section{Methods}

This type of research is a quasi-experiment with a pre-post test design using a randomized controlled trial. The research was conducted in the Darul Imarah Health Center's Work Area from July to September 2020. The study population was all post-partum mothers in the Darul Imarah Community Health Center, Darul Imarah District, Aceh Besar District, purposive sampling totaling 45 people with inclusion and exclusion criteria. The sample criteria consisted of inclusion and exclusion criteria. The inclusion criteria were post-partum mothers who had erythrocyte levels $<4$ million per microliter and $\mathrm{HTC}<37 \%$, were willing to be sampled, had no disease complications, had healthy babies. The exclusion criteria were mothers with digestive problems, taking vitamins. All subjects were divided into 3 (three) groups: treatment group I amounted to 15 people, treatment group II amounted to 15 people, and group III control. A total of 15 people were carried out to test the differences in initial and final erythrocyte and HTC levels in treatment groups I, II, and III using the dependent t-test if the data were not normally distributed Wilcoxon Signed Ranks test. The Wilcoxon test data analysis was used to test the normality of the data. Paired t-test to test each intervention's average pre and post value provided that the data must be normally distributed. Therefore, this study used three intervention groups to test the effect of the intervention between groups using the One-way ANOVA method.

\section{Results}

Data analysis was performed using the Kolmogorov Smirnov test. The Kolmogorov Smirnov test carried out the normality test of this study. The test results are in the Tables 1-4.

Table 1: The results of the test for normality of Erythrocyte and HTC levels after giving guava juice, beet juice, and Fe

\begin{tabular}{lcc}
\hline Group & $\mathrm{p}$-value & $\mathrm{n}$ \\
\hline Erythrocyte levels & 0.001 & 15 \\
After Treatment & & \\
Hematokrit level & 0.001 & 15 \\
After Treatment & & \\
\hline HTC: Hematocrit, Fe: Iron. & &
\end{tabular}

Table 2 The results of the normality test showed a p-value of $0.001<0.05$, which means that the erythrocyte and HTC levels of the treatment and control groups were not normally distributed. Furthermore, data analysis was performed using the Wilcoxon Test.

Table 2: Differences in erythrocyte and HTC levels between before and after giving beet juice

\begin{tabular}{lccc}
\hline Group & Mean & $\mathrm{p}$-value & $\mathrm{n}$ \\
\hline Eritrosit Before after & 8.00 & 0.00 & 15 \\
HCT Before and after & 8.00 & 0.00 & 15 \\
\hline HTC: Hematocrit. & &
\end{tabular}

The results of the table analysis The difference in levels of Erythrocyte and HTC levels between before and after giving beet juice with a p-value of $0.00<0.05$ means that it has a significant difference.

Table 3: Differences in Erythrocyte and HTC levels between before and after treatment of guava juice and $\mathrm{Fe}$

\begin{tabular}{lccc}
\hline Group & Mean & $\mathrm{p}$-value & $\mathrm{n}$ \\
\hline Eritrocit Before and After & 8.43 & 0.00 & 15 \\
Hematokrit Before and after & 8.50 & 0.00 & 15 \\
\hline Fe: Iron, HTC: Hematocrit. & & &
\end{tabular}

Fe: Iron, HTC: Hematocrit.

\section{Wilcoxon test}

\section{Data analysis was performed using the}

The difference in erythrocyte and HTC levels between before and after giving guava and Fe juice with a p-value of $0.00<0.05$ means that it has a significant difference.

Table 4: Differences in erythrocyte levels between the guava group treatment with the beet group and the Fe control group

\begin{tabular}{lccc}
\hline Treatment Group & Mean difference & $\mathrm{p}$-value & $\mathrm{n}$ \\
\hline Group Guava+Fe & 28.20 & 0.001 & 15 \\
Group Bit+Fe & 28.23 & & 15 \\
Group Fe & 12.57 & & 15 \\
\hline Fe: Iron. & & &
\end{tabular}

Table 5 Differences in erythrocyte levels in the Guava $+\mathrm{Fe}$, beet $+\mathrm{Fe}$, and control $(\mathrm{Fe})$ treatment 
Table 5: Differences in HTC levels between the guava group treatment with the beet group and the Fe control group

\begin{tabular}{lccc}
\hline Treatment group & Mean Difference & $\mathrm{p}$-value & $\mathrm{n}$ \\
\hline Group Guava+Fe & 25.77 & 0.001 & 15 \\
Group Bit+Fe & 30.37 & 0.001 & 15 \\
Group Fe & 12.87 & 0.001 & 15 \\
\hline Fe: Iron, HTC: Hematocrit. & & &
\end{tabular}

groups had a significant difference with a p-value of $0.001<0.05$. The difference in the mean difference in erythrocyte levels between the guava and beet treatment groups was 0.03 . It can be concluded that the Beet + Fe treatment group had a higher average difference in erythrocyte levels than the Guava + Fe treatment group and the control group ( $\mathrm{Fe})$. Differences in HTC levels between the Guava, Beet, and Fe treatment groups. The analysis of the differences in HTC levels between the guava + Fe group and the beet + Fe group and the control group (Fe tablet) used the Kruskal Wallis test.

Table 5 HTC levels in the Guava $+\mathrm{Fe}$, beet + $\mathrm{Fe}$, and control $(\mathrm{Fe})$ treatment groups had a significant difference with a $p$-value of $0.001<0.05$. The difference in the mean difference in erythrocyte levels between the guava and beet treatment groups was 0.03 . The Bit $+\mathrm{Fe}$ treatment group had a higher average difference in HTC levels than the Guava + Fe treatment group and the control group (Fe)

\section{Discussion}

The postpartum period is a challenge for many new mothers. Recovery from childbirth requires care and medication, ranging from self-care to care that requires health workers' role. Losing the amount of blood during childbirth causes postpartum mothers to be prone to anemia. Postpartum anemia affects the mother in daily activities, fatigue, postpartum blues, and decreased cognitive abilities. The results showed that there were differences in Erythrocyte and HTC levels before and after Giving Beet Juice. The results showed a significant difference in Erythrocyte and HTC levels between before and after giving beet juice with a $p$-value of $0.00<0.05$. There were significant differences in erythrocyte levels in the Guava + Fe, beet $+\mathrm{Fe}$, and control $(\mathrm{Fe})$ treatment groups with a p-value of $0.001<0.05$. the difference in the average difference in erythrocyte levels between the guava and beet treatment groups was 0.03 . Bit $+\mathrm{Fe}$ had a higher mean erythrocyte level, different from the Guava + treatment and control groups $(\mathrm{Fe})$. There was a significant difference in HTC levels in the Guava $+\mathrm{Fe}$, beet $+\mathrm{Fe}$, and control $(\mathrm{Fe})$ treatment groups with a p-value of $0.001<0.05$. the difference in the average difference in erythrocyte levels between the guava and beet treatment groups was 0.03 . Bit + Fe had a higher mean difference in HTC levels than the Guava + treatment and control groups $(\mathrm{Fe})$. There was a significant increase in the value of the Erythrocyte Index after consuming beets. Consumption of 8 grams of beetroot for 20 days led to an increase in $\mathrm{Hb}$, ferritin, and serum Fe levels, as well as a decrease in transferrin and total Fe-binding capacity levels in seven women aged 22-24 years [18]. Consumption of beets in juice (100-200 mL) increases $\mathrm{Hb}$ levels [19]. Also, administering $200 \mathrm{~mL}$ of beet juice for six weeks led to elevated levels of HTC, RBC, Fe, and ferritin [20]. Giving beetroot in powder form and Fe-based supplements for 14 days in women with anemia causes an increase in $\mathrm{Hb}$ levels, HTC, and the number of erythrocytes [21]. Beet juice lowers blood pressure and is consumed as part of a regular diet in adults [22]. The pigment content in beets is an antioxidant compound that affects the resistance of erythrocyte walls. The erythrocyte membrane is one of the cell membranes that are susceptible to free radical attack. If free radicals attack the erythrocyte membrane, the fluidity of the cell membrane will be disturbed, which can cause cell death so that there will be changes in the number of erythrocytes and $\mathrm{Hb}$ levels. The results also found differences in erythrocyte and HTC levels between before and after giving Guava and Fe juices with a $p$-value of $0.001<0.05$. This value implies that it has a significant difference between before and after treatment. The beet + Fe treatment group had a higher mean difference in erythrocyte levels compared to the Guava + fe treatment group and the control group $(\mathrm{Fe})$. HTC levels in the Guava + Fe, beet + Fe, and control $(\mathrm{Fe})$ treatment groups had a significant difference with a $p$-value of $0.001<0.05$. The difference in the average difference in erythrocyte levels between the guava and beet treatment groups was 0.03 . It can be concluded that the Beet $+\mathrm{Fe}$ treatment group had a higher average difference in HTC levels than the Guava + fe treatment group and the control group ( $\mathrm{Fe})$. Guava juice providing $200 \mathrm{mg}$ A.A. has marginal effects on $\mathrm{Hb}$ and P.F. concentrations and is rich in $\mathrm{Fe}$ [23]. Consumption of guava fruit simultaneously with ricebased foods increases the bioavailability of $\mathrm{Fe}$ [24]. Guava has anti-oxidative, anti-inflammatory, antidiabetic properties, lots of Vitamin C, flavonoids, and polyphenol compounds [25], [26]. In previous studies, guava extract can reduce reactive oxygen species (ROS) levels, interleukin-6, tumor necrosis factor- $\alpha$, and interleukin-1 $\beta$ in the kidney of type 1 diabetic rats [27].

\section{Conclusion}

There was a significant difference in the levels of erythrocytes and HTC between before and after giving guava juice and beet juice to postpartum mothers with a $p$-value of $0.00<0.05$. Beet juice increases the average level of erythrocytes and HTC, which is higher than guava juice in postpartum mothers at the Puskesmas, Darul Imarah District, Regency. 


\section{References}

1. World Health Organization. Haemoglobin Concentrations for the Diagnosis of Anaemia and Assessment of Severity. Vitamin and Mineral Nutrition Information System. Document Reference WHO. NMH/NHD/MNM/11.1. Geneva: World Health Organization; 2011.

2. McLean E, Cogswell M, Egli I, Wojdyla D, de Benoist B. Worldwide prevalence of anaemia, WHO vitamin and mineral nutrition information system, 1993-2005. Public Health Nutr. 2009;12(4):444-54. https://doi:10.1017/S1368980008002401 PMid: 18498676

3. Cunningham FG, Leveno KJ, Bloom FL, Hauth JC, Wenstrom KD. In: Jahani BG, editor. Williams Obstetrics. Tehran: Golban Publication; 2004. p. 884-91.

4. Stoev S, Dikov I, lovchev S, Ivanov S. Khemoreologichni parametri $v$ prognozata na riska ot retardatsiia na ploda pri bremennost $\mathrm{s}$ arterialna khipertoniia. [Hemorheological parameters in the prognosis of the risk of fetal retardation in pregnancy with arterial hypertension]. Akush Ginekol (Sofiia). 1996;35(4):23-4. Bulgarian.

\section{PMid:9254562}

5. Romano M, Cacciatore A, Giordano R, La Rosa B. Postpartum period: Three distinct but continuous phases. J Prenat Med. 2010;4(2):22-5.

PMid:22439056

6. Brown JS, Posner SF, Stewart AL. Urge incontinence: New health-related quality of life measures. J Am Geriatr Soc. 1999;47(8):980-8. $\quad$ https://doi:10.1111/j.15325415.1999. tb01294.x. PMid:10443860

7. Albacar G, Sans T, Martín-Santos R, García-Esteve L, Guillamat R, Sanjuan J, et al. An association between plasma ferritin concentrations measured $48 \mathrm{~h}$ after delivery and postpartum depression. J Affect Disord. 2011;131(1-3):136-42. https://doi:10.1016/j.jad.2010.11.006

PMid:21130499

8. Murray-Kolb LE, Beard JL. Iron deficiency and child and maternal health. Am J Clin Nutr. 2009;89(3):946S-950S. https:// doi:10.3945/ajcn.2008.26692D

PMid:19158210.

9. Beard JL, Hendricks MK, Perez EM, Murray-Kolb LE, Berg A, Vernon-Feagans $L$, et al. Maternal iron deficiency anemia affects postpartum emotions and cognition. J Nutr. 2005;135(2):26772. https://doi:10.1093/jn/135.2.267

PMid:15671224

10. Bothwell TH. Iron requirements in pregnancy and strategies to meet them. Am J Clin Nutr. 2000 Jul;72(1 Suppl):257S-64. https://doi:10.1093/ajcn/72.1.257S PMid:10871591

11. Parisi F, Berti C, Mandò C, Martinelli A, Mazzali C, Cetin I. Effects of different regimens of iron prophylaxis on maternal iron status and pregnancy outcome: A randomized control trial. J Matern Fetal Neonatal Med. 2017;30(15):1787-92. https://doi: 10.1080/14767058.2016.1224841

PMid:27588568

12. Woldegebriel AG, Gebrehiwot GG, Desta AA, Ajemu KF, Berhe AA, Woldearegay TW, et al. Determinants of anemia in pregnancy: Findings from the Ethiopian health and demographic survey. Anemia 2020;2020:2902498. https://doi. org/10.1155/2020/2902498

PMid:32566286

13. Vora $M$, Gruslin A. Erythropoietin in obstetrics. Obstet Gynecol Surv. 1998;53(8):500-8. https:// doi:10.1097/00006254-199808000-00023

PMid: 9702790

14. Corwin EJ, Murray-Kolb LE, Beard JL. Low hemoglobin level is a risk factor for postpartum depression. J Nutr. 2003;133(12):413942. https://doi:10.1093/jn/133.12.4139

PMid: 14652362

15. Sibagariang EE. Reproductive Health for Women. Jakarta: Trans Info Media; 2010. p. 61-5.

16. Georgiev VG, Weber J, Kneschke EM, Denev PN, Bley T, Pavlov Al. Antioxidant activity and phenolic content of betalain extracts from intact plants and hairy root cultures of the red beetroot Beta vulgaris cv. Detroit dark red. Plant Foods Hum Nutr. 2010;65(2):105-11. https://doi:10.1007/s11130-010-0156-6 PMid:20195764

17. Zielińska-Przyjemska M, Olejnik A, Dobrowolska-Zachwieja A, Grajek W. In vitro effects of beetroot juice and chips on oxidative metabolism and apoptosis in neutrophils from obese individuals. Phytother Res. 2009;23(1):49-55. https://doi:10.1002/ptr.2535 PMid: 18814207

18. Lotfi M, Azizi M, Tahmasbi W, Bashiri P. The effects of consuming 6 weeks of beetroot juice (Beta vulgaris L.) on hematological parameters in female soccer players. J Kermanshah Univ Med Sci. 2018;22:e82300. https://doi.org/10.5812/jkums.82300

19. Kavitha SR, Dinesh K. An experimental study to determine the effectiveness of beetroot juice on hemoglobin among girls of selected hostel girls, Bidar, Karnataka. World J Adv Healthc Res. 2020;4:55-8.

20. Triana H, Hadisaputro S, Djamil M. Effect of beet powder (Beta vulgaris L.) with Fe supplementation on increasing hemoglobin, hematocrit, and erythrocyte levels in pregnant women with anemia. STRADA J Ilm Kesehat. 2020;9:893-9. https://doi. org/10.30994/sjik.v9i2.354

21. Saini RK, Manoj P, Shetty NP, Srinivasan K, Giridhar P. Dietary iron supplements and Moringa oleifera leaves influence the liver hepcidin messenger RNA expression and biochemical indices of iron status in rats. Nutr Res. 2014;34(7):630-8. https://doi. org/10.1016/j.nutres.2014.07.003

PMid:25150122

22. Coles LT, Clifton PM. Effect of beetroot juice on lowering blood pressure in free-living, disease-free adults: A randomized, placebo-controlled trial. Nutr J. 2012;11:106. https:// doi:10.1186/1475-2891-11-106

PMid:23231777

23. Monárrez-Espino J, López-Alarcón M, Greiner T. Randomized placebo-controlled trial of guava juice as a source of ascorbic acid to reduce iron deficiency in Tarahumara indigenous schoolchildren of Northern Mexico. J Am Coll Nutr. 2011;30(3):191-200. https:// doi:10.1080/07315724.2011.10719960

PMid:21896877

24. Nair KM, Brahmam GN, Radhika MS, Dripta RC, Ravinder P, Balakrishna N, et al. Inclusion of guava enhances non-heme iron bioavailability but not fractional zinc absorption from a ricebased meal in adolescents. J Nutr. 2013;143(6):852-8. https:// doi:10.3945/jn.112.171702

PMid:23596161

25. Li PY, Hsu CC, Yin MC, Kuo YH, Tang FY, Chao CY. Protective effects of red guava on inflammation and oxidative stress in streptozotocin-induced diabetic mice. Molecules. 2015;20(12):22341-50. https://doi:10.3390/ molecules201219831 PMid:26703532

26. Flores G, Dastmalchi K, Wu SB, Whalen K, Dabo AJ, Reynertson KA, et al. Phenolic-rich extract from the costa rican guava (Psidium friedrichsthalianum) pulp with antioxidant and anti-inflammatory activity. Potential for COPD therapy. 
Food Chem. 2013;141(2):889-95. https://doi:10.1016/j. foodchem.2013.03.025

PMid:23790863

27. Eidenberger T, Selg M, Krennhuber K. Inhibition of dipeptidyl peptidase activity by flavonol glycosides of guava (Psidium guajava L.): A key to the beneficial effects of guava in Type II diabetes mellitus. Fitoterapia. 2013 Sep;89:74-9. https:// doi:10.1016/j.fitote.2013.05.015

PMid:23707747 